Preprint: Aishwarya Mundada, Kunal Shah, Joshua M. Pearce. Levelized cost of electricity for solar photovoltaic, battery and cogen hybrid systems, Renewable and Sustainable Energy Reviews 57, (2016), 692-703.

\title{
Levelized Cost of Electricity for Solar Photovoltaic, Battery and Cogen Hybrid Systems
}

\author{
Aishwarya S. Mundada ${ }^{1}$, Kunal K. Shah ${ }^{1}$, J.M. Pearce ${ }^{1,2, *}$
}

1. Department of Electrical \& Computer Engineering, Michigan Technological University

2. Department of Materials Science \& Engineering, Michigan Technological University

* Contact author:

601 M\&M Building

1400 Townsend Drive

Houghton, MI 49931-1295

pearce@mtu.edu

\begin{abstract}
The technological development and economic of scale for solar photovoltaic (PV), batteries and combined heat and power (CHP) have led to the technical potential for a mass-scale transition to offgrid home electricity production for a significant number of utility customers. However, economic projections on complex hybrid systems utilizing these three technologies is challenging and no comprehensive method is available for guiding decision makers. This paper provides a new method of quantifying the economic viability of off-grid PV+battery+CHP systems by calculating the levelized cost of electricity (LCOE) of the technology to be compared to centralized grid electricity. The analysis is inherently conservative as it does not include the additional value of the heat form the CHP unit. A case study for residential electricity and thermal demand in an extreme worst case environment (Houghton, Michigan) is provided to demonstrate the methodology. The results of this case study show that with reasonable economic assumptions and current costs, PV+battery+CHP systems already provide a potential source of profit for some consumers to leave the grid. A sensitivity analysis for LCOE of such a hybrid system was then carried out on the capital cost of the three energy sub-systems, capacity factor of PV and CHP, efficiency of the CHP, natural gas rates, and fuel consumption of the CHP. The results of the sensitivity provide decision makers with clear guides to the LCOE of distributed generation with off-grid PV+battery+CHP systems and offer support to preliminary analysis that indicated a potential increase in grid defection in the U.S. in the near future.
\end{abstract}

Keywords: photovoltaic; cogeneration; off-grid; combined heat and power; CHP; levelized cost of electricity; battery; storage 
Preprint: Aishwarya Mundada, Kunal Shah, Joshua M. Pearce. Levelized cost of electricity for solar photovoltaic, battery and cogen hybrid systems, Renewable and Sustainable Energy Reviews 57, (2016), 692-703.

\section{Nomenclature:}

$\mathrm{C}_{\mathrm{cf}}$ : Capacity factor of $\mathrm{CHP}(\%)$

$\mathrm{C}_{\mathrm{s}}$ : CHP system size $(\mathrm{kW})$

$\mathrm{d}_{1}$ : degradation rate of the PV module per year (\%)

$\mathrm{d}_{2}$ : degradation rate of the CHP unit per year (\%)

dr: discount rate on the hybrid system per year (\%)

$\mathrm{E}_{\text {chp }}$ : Electrical power output of CHP unit $(\mathrm{kW})$

$\mathrm{E}_{\mathrm{fff}}$ : Efficiency of CHP unit (\%)

$\mathrm{E}_{\text {tchp }}$ : Rated energy from CHP unit yearly ( $\left.\mathrm{kWh} / \mathrm{year}\right)$

$\mathrm{E}_{\mathrm{tpv}}$ : Rated energy from Solar PV module yearly (kWh/year)

$\mathrm{F}_{\text {chp: }}$ : Fuel cost of the CHP unit yearly (\$)

$\mathrm{F}_{\text {con }}$ : Fuel consumed by the CHP unit yearly (MMBTU/year)

$\mathrm{F}_{\mathrm{c}}$ : Cost of fuel per unit thermal energy (\$MMBTU)

$\mathrm{H}_{\text {chp }}$ : number of hours CHP operates in a year (hours)

I: interest rate on the hybrid system for $100 \% \operatorname{debt}(\%)$

$\mathrm{I}_{\mathrm{pv}}$ : Installation cost of Solar PV (\$)

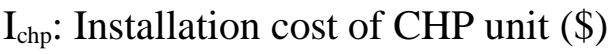

$\mathrm{I}_{\mathrm{bat}}$ : Installation cost of battery storage unit (\$)

$\mathrm{M}_{\mathrm{pv}}$ : Maintenance cost of Solar PV yearly (\$)

$\mathrm{M}_{\text {chp: }}$ : Maintenance cost of CHP unit yearly (\$)

$\mathrm{O}_{\mathrm{pv}}$ : Operation cost of Solar PV yearly $(\$)$

$\mathrm{O}_{\text {chp }}$ : Operation cost of the CHP unit yearly (\$)

$\mathrm{P}_{\mathrm{cf}}:$ Capacity factor of $\mathrm{PV}(\%)$

$\mathrm{P}_{\mathrm{s}}$ : PV power system size $(\mathrm{kW})$

$\mathrm{R}_{\text {bat }}$ : Cost of battery replacement considered after every 10 years (\$)

$\mathrm{T}:$ loan return term or lifetime of the hybrid system (years)

$\mathrm{T}_{\text {chp }}$ : Thermal output of CHP unit (MMBTU/hr)

$\mathrm{V}_{\text {chp }}$ : Variable Operation and Maintenance cost of the CHP unit yearly (\$) 
Preprint: Aishwarya Mundada, Kunal Shah, Joshua M. Pearce. Levelized cost of electricity for solar photovoltaic, battery and cogen hybrid systems, Renewable and Sustainable Energy Reviews 57, (2016), 692-703.

\section{Introduction}

Technical improvements and scaling have resulted in a significant reduction in solar photovoltaic (PV) module costs, which have resulted in PV industry growth both globally as well as in U.S. [1]. In many regions there have been favorable policies for solar energy due to the positive public response and support for growth of solar energy [2-7]. High exergy electricity from PV is not only reliable, safe and sustainable [8-11], but now it has become an economical way of providing global society's energy needs as well [12-13]. As the demand for PV installation continues to increase, the costs continue to decline feeding a virtuous cycle [14-19]. In some regions of U.S. the solar levelized cost of electricity for small-distributed on-grid PV systems is already competitive with conventional utility electrical rates [12, 20-21].

This represents an economic threat to conventional electric utility business models and in response utilities are using a number of mechanisms to discourage the distributed renewable energy generation market including: i) revoking or repealing net metering legislation [22-25]; ii) placing caps on distributed generation [27-28]; iii) specifying solar grid charges [29-32]; iv) continuing manipulation of customer charges to act as disincentives of both energy efficiency and distributed renewable energy [33-35]; and v) placing temporary prohibition of activities on state Renewable Portfolio Standards [36].

Many of the arguments (e.g. iii) are framed as costs of an inherently intermittent electrical source such as solar. However, the potential for economic dispatchable distributed power becomes possible with the simultaneous decline of the cost of battery storage. Current battery costs are between $\$ 600-1,000 / \mathrm{kWh}$. The U.S. DOE expects that this cost will decline further to reach $\$ 225 / \mathrm{kWh}$ in 2020 and will further drop below $\$ 150 / \mathrm{kWh}$ in the longer term [37]. Economy of scale will also factor into future battery prices, especially with Tesla's battery GigaFactory, which will shortly have battery packs (Power Wall) available for $\$ 350 / \mathrm{kWh}$ for home use [38]. However, in many applications (e.g. northern U.S. communities) where a battery bank would need to be prohibitively large to cover the load with PV system alone, such systems can be coupled to a cogeneration or combined heat and power (CHP) system.

The passage of the Public Utility Regulatory Policies Act (PURPA) in November 1978 [39], created the impetus for a resurgence of co-generation and significant growth in CHP capacity. Conventional generation is inherently inefficient, only converting on average about a third of the input fuel's potential energy into usable energy. When comparing overall CHP system efficiency to the typical central power station (for electricity) and boiler system (for steam) scenario, CHP offers reductions in total primary fuel consumption on the order of $30 \%$ to $35 \%$, which results in a similar $\mathrm{CO}_{2}$ emissions reduction, consuming the same fuels [40]. However, if coal-fired electric generation is compared to natural-gas fired CHP systems the result is $\mathrm{CO}_{2}$ emission reductions approaching $60 \%$ and even greater reductions in pollutants such as $\mathrm{SO}_{2}, \mathrm{NO}_{\mathrm{x}}$ and mercury [41]. More than two-thirds of the CHPs in the U.S. are fueled with natural gas, but renewable biomass and process wastes are also potential fuel sources [41]. According to a 2012 joint report by U.S. D.O.E. and U.S. E.P.A., CHP makes up about 8 percent of U.S. total generating capacity with an installed capacity of about $82 \mathrm{GW}$ (2012) [42]. The CHP technologies have also improved and are now available at a household scale. In a review comparing various CHP technologies depending on size, cost, efficiency and performance 
Preprint: Aishwarya Mundada, Kunal Shah, Joshua M. Pearce. Levelized cost of electricity for solar photovoltaic, battery and cogen hybrid systems, Renewable and Sustainable Energy Reviews 57, (2016), 692-703.

parameters for residential use, CHP modules with internal combustion engine technology were found to be more efficient [43-45]. Finally, the development of shale gas has had a significant moderating effect on natural gas prices [40]. For example, average residential natural gas rates for Michigan in 2009 were \$11.30/MMBTU and in 2014 they were \$8.99/MMBTU [46]. This has assisted in the economic viability of small-scale CHP units.

Hence, these three technological developments in PV, batteries and CHP have led to the possibility of grid defection (moving completely off-grid) for a significant number of utility customers and is projected to increase in the future [47]. However, economic projections on such complex systems utilizing multiple technologies and fuel sources is challenging and no comprehensive review is available for guiding decision makers. This paper provides such a means by quantifying the economic viability of off-grid PV+battery+CHP systems by calculating the levelized cost of electricity (LCOE) of the technology and a case study for residential electricity and thermal demand in Houghton, Michigan is provided to demonstrate the methodology. A sensitivity analysis for LCOE of such a hybrid system is then carried out on the following factors: capital cost of the three components, capacity factor of PV and CHP, efficiency of the CHP, natural gas rates, and fuel consumption of the CHP. The results enable the cost of distributed generation with off-grid PV+battery+CHP systems to be compared to the cost of electricity with the conventional grid. The results for potential grid defection are discussed.

\section{Background}

The simplified block diagram of the modeled PV + CHP + battery hybrid system considers only AC loads [48] and is depicted in Figure 1. Such a hybrid system is used to satisfy electrical as well as thermal load demand for a residential single-family detached homes. The hybrid system consists of PV and CHP unit, which are both used to generate electricity. Also the waste heat from co-generation units can be used primarily for space heating and cooling and domestic water heating. The use of cogeneration units in this way is optimal for energy management [49-51]. Moreover the CHP unit also generates thermal energy, which it uses to partially fulfill thermal load demand and thus offsets the primary furnace and fuel source (e.g. natural gas furnace). The output of PV and the energy stored in the battery is DC, which necessitates a DC-AC inverter to supply the AC load. Moreover, as the output of CHP unit is $\mathrm{AC}$, any excess $\mathrm{AC}$ output has to be converted into $\mathrm{DC}$ form before storing it in the battery unit. Thus, an AC to DC rectifier is incorporated for this purpose. It should be noted, the dispatch strategy of the system will be reliant on both the load data and the fuel economics for a given region. Parallel topology is employed for the electrical component of the system [52]. Here, the priority given to fulfill the electrical demand will be solar PV followed by the storage battery and finally the CHP unit, in order to minimize fuel use and greenhouse gas emissions. Thus, the PV unit will try to satisfy the AC load demand. If it is incapable of satisfying, then PV and the battery unit will fulfill the load demand, which will help to increase system efficiency. If still the AC load demand is not satisfied the remaining load demand will be served by the CHP unit [53].

\section{Methodology}

LCOE methods for PV are well established [54-57] and recently standardized in [12]. LCOE of CHP units is slightly more complex because of potentially unknown expenditures for carbon dioxide emissions, but is also well established taking into account the amount of electricity produced, the 
Preprint: Aishwarya Mundada, Kunal Shah, Joshua M. Pearce. Levelized cost of electricity for solar photovoltaic, battery and cogen hybrid systems, Renewable and Sustainable Energy Reviews 57, (2016), 692-703.

discount factor, investment costs; operations and maintenance costs; fuel costs; carbon costs; and decommissioning costs [58-61]. Here the LCOE calculation requires determining the cost of generation of energy by the hybrid system and the energy generated by the system in its lifetime and gives cost of energy in $(\$ / \mathrm{kWh})$. As LCOE is sensitive to the input assumptions a sensitivity analysis is carried out encompassing the following variables:

- Capital cost of the three systems:

1. PV $(\$ 0.50 / \mathrm{W}$ to $\$ 4.00 / \mathrm{W})$,

1. Battery storage $\$ 250 / \mathrm{kWh}$ to $\$ 1,000 / \mathrm{kWh}$ ) and

2. $\mathrm{CHP}(\$ 500 / \mathrm{kW}$ to $\$ 1,400 / \mathrm{kW})$.

The high capital costs are the current market prices as of this writing.

- Efficiency of the CHP module: $80 \%$ to $98 \%$.

- Capacity factor of the PV: (13\% to $18 \%$ ) and consequently CHP module (55\% to $14 \%$ ).

- Financing terms: interest rate $(0 \%$ to $10 \%)$ and discount rate $(0 \%$ to $10 \%)$.

- Fuel cost of natural gas being consumed by the CHP module: (\$6/MMBTU to \$15/MMBTU)

It should be noted that starting from year one until the loan term, $\mathrm{T}$, the operation and maintenance, fuel cost and the interested amount is considered just as in the case with the generated energy by the system. In this paper the LCOE method represented does not include any incentives as well as any decommissioning cost, carbon cost or refurbishment costs.

The installation cost is taken out of the summation as it is just considered initially. The installation cost will include the cost of solar PV, battery and the CHP module and is given by:

$\mathrm{I}=\mathrm{I}_{\mathrm{pv}}+\mathrm{I}_{\mathrm{chp}}+\mathrm{I}_{\mathrm{bat}}$

The operation and maintenance will include the operation and maintenance cost for solar PV (including inverter replacement) and CHP module along with variable operation and maintenance cost of CHP module and replacement cost of battery is:

$\mathrm{O}=\mathrm{O}_{\mathrm{pv}}+\mathrm{O}_{\mathrm{chp}}+\mathrm{M}_{\mathrm{pv}}+\mathrm{M}_{\mathrm{chp}}+\mathrm{V}_{\mathrm{chp}}+\mathrm{R}_{\mathrm{bat}}$

The LCOE of the hybrid system can be determined using:

$$
L C O E=\frac{I+\sum_{n=1}^{T} \square \frac{\left(I \times i+O+F_{c h p}\right)}{\left(1+d_{r}\right)^{n}}}{\sum_{n=1}^{T} E_{t p v} \times\left(1-d_{1}\right)^{n}+\frac{E_{t c h p} \times\left(1-d_{2}\right)^{n}}{\left(1+d_{r}\right)^{n}}}
$$

where:

$\mathrm{E}_{\mathrm{tpv}}=8760 \mathrm{hrs} /$ year $\mathrm{x} \mathrm{P}_{\mathrm{s}} \times \mathrm{P}_{\mathrm{cf}}$

and 
Preprint: Aishwarya Mundada, Kunal Shah, Joshua M. Pearce. Levelized cost of electricity for solar photovoltaic, battery and cogen hybrid systems, Renewable and Sustainable Energy Reviews 57, (2016), 692-703.

$\mathrm{E}_{\text {tchp }}=8760 \mathrm{hrs} /$ year $\mathrm{x} \mathrm{C}_{\mathrm{s}} \times \mathrm{C}_{\mathrm{cf}}$

The cost of fuel can be determined by multiplying the fuel consumption per hour by the number of hours the CHP is working in a year, which is then multiplied with the cost of fuel in that area:

$\mathrm{F}_{\text {chp }}=\mathrm{F}_{\text {con }} \times \mathrm{F}_{\mathrm{c}} \times \mathrm{H}_{\text {chp }}$

The fuel consumption can be found out by dividing total electrical and thermal output generated by the CHP by the efficiency of the CHP unit [62-64]:

$$
F_{\text {con }}=\frac{\left(\left(E_{c h p} \times 3.143\right)+T_{c h p}\right)}{E_{f f}}
$$

As can be seen by equation 3, the LCOE greatly depends on the capital costs of the PV, battery and CHP. It also varies depending on the operation and maintenance costs of the sub-systems. Moreover, the fuel cost also affects the LCOE of the hybrid system. The fuel cost depends on the fuel consumption of the CHP unit, which depends on the efficiency and the power to heat ratio of the CHP unit.

\section{Theory and Calculations for Determining LCOE of the Hybrid System}

The choice of discount rate, system costs, average system lifetime and the degradation rate of the entire system every year.

\section{1) Discount rate}

The choice of discount rate can vary depending on the location, the life time of the project and the technologies being used based on investors' perception of financial risk. The DOE discount rate for projects related to energy conservation and renewable energy resources in 2013 was 3\% [65], which will be used here.

\section{2) System cost}

System component cost not only depends on the capacity and the variability from vendors, but also on the type of the system and the location where the system is being installed. Installation costs vary widely as a function of location and depends on the engineering costs, permitting and regulations, labor costs and the remainder of balance of system costs (BOS). Capital costs of the major system components are all decreasing.

The PV unit price, is highly dependent on the type of solar PV system, location and type of the dwelling. For an instance, a thin-film solar PV system cost less per Watt as compared to a crystalline silicon PV system [66-67]. The installed prices for residential PV continued their precipitous decline in 2014, falling year-over-year by 12-15\% depending on system size range [1]. The installation cost include the module price, labor cost, electrical BOS cost, structural BOS cost, inverter costs, engineering \& PII cost [1]. In general, labor cost and BOS of a solar PV system adds up to 50\% of the system cost [68], but strategies are being developed to halve these prices [69]. Through industrial symbiosis and 
Preprint: Aishwarya Mundada, Kunal Shah, Joshua M. Pearce. Levelized cost of electricity for solar photovoltaic, battery and cogen hybrid systems, Renewable and Sustainable Energy Reviews 57, (2016), 692-703.

manufacturing facilities the solar manufacturing prices have been declining on the economic scale [66, 70, 71]. Finally, installation costs are expected to decrease with technological experience, although not as drastically as hardware costs [72]. The installed PV system median costs for location are summarized in Table 1. Due to technical advancement PV modules are available at historically extremely low prices such as \$0.69/W for Canadian Solar CS6P-280P [75]. The major contribution to the PV capital cost in U.S. is the soft cost which is around 50-70\% of the total PV system installation cost which is double the soft cost incurred by the PV installation in Germany (i.e. the U.S. solar PV soft cost is $\sim \$ 0.49 / \mathrm{W}$ whereas for Germany it is only $\sim \$ 0.18 / \mathrm{W}$ ) [76].

The engineering, capital cost and efficiency for CHP units as a function of the prime mover technology $[44,77]$. The fuel cost varies depending on the efficiency of the CHP unit and the location where the system is installed. Table 2, compares the efficiency of various micro CHP units, which are both sufficient for residential use and available on the market [78]. These are put in context in Table 3, which compares capital cost of different prime mover technologies to large scales [68, 77]. It can be observed from the Table 2 that CHP with ICE technology is suitable and efficient for such type of hybrid system.

Moreover, the cost is also declining and the lifetime is increasing for electrical storage technology as a whole, although it depends on the type of the battery being used for the system and the battery rating, and number of batteries connected in series or parallel. Historically, deep cycle batteries were preferred for off-grid applications. For example, Trojan T105 RE, with 1000 cycles to $80 \%$ discharge rate has a normal lifespan of 10 to 12 years and cost of $\$ 0.16 / \mathrm{kWh}$ for life time of battery [79]. These battery costs along with the battery technology are evolving quickly as noted above.

Thus, the LCOE of the system is obviously sensitive towards the system cost and sensitivity analysis is carried out. For the case study presented here the capital cost of PV is considered to be $\$ 4 / \mathrm{W}$ and installation cost of CHP is considered to be $\$ 1,400 / \mathrm{kW}$.

\section{3) Financing}

Financing depends on the credit of the individual and the tax laws, which also varies depending on location. Financing can be government incentives, loans, equity financing, mortgage, or debt financing. Debt financing is common as interest payment does not on include taxes. For the case study, $100 \%$ debt financing will be used. Moreover, the loan period is different from the life time of the system, it is a guarantee period.

\section{4) Life time of the hybrid system}

The life time of hybrid system depends on the life time of the PV as well as CHP module. The average life time of PV module is considered to be 25 years in the analysis here to be conservative, although it is known that PV operate much longer. The life time of a CHP unit is a minimum 10-20 years. Operation and maintenance cost increases with the time and is mainly due to inverter and battery replacement (at 10 years) and to insure the proper performance of the CHP unit. The fuel cost depends on the type of fuel required for the CHP unit, generally natural gas or propane based CHP units are available in market. Here natural gas will be considered primarily for economic reasons and the 
Preprint: Aishwarya Mundada, Kunal Shah, Joshua M. Pearce. Levelized cost of electricity for solar photovoltaic, battery and cogen hybrid systems, Renewable and Sustainable Energy Reviews 57, (2016), 692-703.

technical feasibility of scaling. Table 4 and 5 provide the EIA-2015 natural gas rates for the state of Michigan [46].

\section{5) Degradation rate and the energy generated by the system}

The energy output from PV depends on the degradation rate of the modules. The degradation rates for amorphous silicon PV is 0.5-1.0\%/year, for crystalline silicon it is $0.1-0.5 \%$, for polycrystalline silicon PV it is $0.1-1.0 \%$ and for cadmium telluride 0.1-0.5\%/year [80-81]. This degradation is due to chemical and material processes such as weathering, oxidation, corrosion and thermal stress. The degradation rate of the CHP module depends on the type of the technology of prime mover; for all the technologies, however, the degradation annually is below $0.5 \%$ [44]. For the case study in this paper the annual degradation of the PV module and the CHP module with internal combustion engine prime mover is considered to be $0.5 \%$.

\section{4) Results}

\subsection{Case study: Houghton, Michigan, USA.}

A case study was chosen with relatively challenging resources. Houghton, MI is located in the upper peninsula for Michigan, thus it has relatively long winters, poor solar flux distribution and high heat loads relative to most of the rest of the U.S. The case study is for residential sector in Houghton, MI with average electric demand of $9,128 \mathrm{kWh} / \mathrm{year}$ [82] and thermal demand of 98.3MMBTU/year [83]. As it is a low-population density isolated community the installation costs of PV are above the national average and will be assumed here to be $\$ 4.00 / \mathrm{W}$. Moreover, the minimum capital cost of the PV considered for the sensitivity is $\$ 0.5 / \mathrm{W}$. The size of PV required for fulfilling the load demand is $8.133 \mathrm{~kW}$ [48]. Whereas the CHP module is assumed to have a capital cost $\$ 1,400 / \mathrm{kW}$ with an engineering cost of $450 \$[44,77]$. The CHP unit with ICE prime mover technology has different minimum cost ranging from $\$ 800-\$ 1400 / \mathrm{W}[77,84,85]$. Thus, a minimum capital cost of $\$ 500 / \mathrm{kW}$ was considered for sensitivity analysis. The size of CHP required to fulfill the load demand on an hourly basis throughout the year is $1 \mathrm{kWe}$ [48]. A battery storage unit considered is deep-cycle batteries with nominal voltage 48V and 1199A-h costs around \$2,000 and has a lifetime of 10 years or more (although as noted earlier this is likely to decline considerably as Tesla batteries become available).

Battery backup banks can be made up of many small batteries which are connected in series and or parallel to give the wattage (V-A) capacity needed. The optimal sized deep cycle lead acid battery storage unit for $1 \mathrm{kWe}$ of CHP unit is 4 batteries in series and 8 in parallel for a PV array of $8.1 \mathrm{~kW}$ and a CHP of $1 \mathrm{kWe}$ for a total battery size of $300 \mathrm{Ah}$ [48]. The life span duration of such a battery storage unit is 10 years or more [86,87].

From the results of the HOMER simulation shown in Figure 2 of such an optimized hybrid system run using the above PV, CHP and battery sizing it can be observed that system is able to fulfill the load demand completely for residence in Houghton, MI [48]. It can also be observed that the operating hours for all the three units are different and also varies according to the monthly AC load demand and the solar hours. The thermal load demand of the residence is fulfilled by CHP unit as well as boiler.

The engineering cost for the hybrid system should also be considered to get precise results. Here it is assumed that the dispatch strategy considered ensure that the CHP operational time is minimized to 
Preprint: Aishwarya Mundada, Kunal Shah, Joshua M. Pearce. Levelized cost of electricity for solar photovoltaic, battery and cogen hybrid systems, Renewable and Sustainable Energy Reviews 57, (2016), 692-703.

reduce the fuel consumptions and the concomitant fuel costs and GHG emissions. The capacity factor of the PV is considered to be $15.3 \%$ for Houghton based on solar data and that of the CHP is considered to be $36.28 \%$ with an efficiency of the CHP module of $83 \%$ [48]. Moreover, historically the efficiency of ICE technology based CHP module varies from 75-80\% [77, 84]. Today, the CHP modules with ICE technology available on the market have efficiencies of around 80\%-95\% [88-91]. Thus for the sensitivity analysis the efficiency of CHP unit has been considered to be $80 \%-98 \%$. Along with it $100 \%$ debt financing was used. The operation cost for the PV is $1.5 \%$ of the PV installation cost; whereas the maintenance cost, which is mainly due to inverter replacement, is $9 \%$ of the PV installation cost [12]. The battery is to be replaced after 10 years and cost of the replacement is considered in the operation and maintenance cost. The operation and maintenance cost for ICE based CHP unit is $\$ 50 /$ year whereas the variable operation and maintenance cost is $\$ 0.08 / \mathrm{kWh}$ [44]. The fuel used by the CHP module is natural gas and in Houghton the rates are \$8.90/MMBTU [46]. Thus, following the equations above the total fuel cost for the CHP module is $\$ 341.53 / y e a r$.

The electricity price for residential sector in Houghton varies from $\$ 0.21 / \mathrm{kWh}$ to $\$ 0.24 / \mathrm{kWh}$ [92], electric utility company annual reports the electricity rates for Houghton in 2013 was $\$ 0.22 / \mathrm{kWh}$. It has been observed that this electricity rates are escalating. For example: the electricity rate in Houghton in 2003 was $\$ 0.1459 / \mathrm{kWh}$ and in 2013 it was $\$ 0.22 / \mathrm{kWh}$ (i.e. an increase by almost $50 \%$ in a duration of 10 years). Thus, to compare the LCOE of the hybrid system with the rates of electricity it is important to consider the escalation rate of electricity each year. This escalation rate is due to a number of factors that are difficult to estimate so the estimated cost of electricity after 25 years with varying escalation rates $0 \%$ to $6 \%$ is shown in Figure 3.

Figure $4 \mathrm{~A}-\mathrm{F}$ shows the effects on the LCOE of the hybrid system of financing assumptions. The LCOE of the system with with different discount rates of $0 \%, 3 \%, 5 \%$ and $10 \%$ and interest rates of $0 \%, 1 \%, 2 \%, 3 \%, 5 \%$ and $10 \%$ with all other factors maintained for a loan term vary from 25 years are shown. For Figure 2 it is clear that LCOE decreases as the interest rate falls for the same discount rate. The LCOE for $0 \%$ interest rate and $0 \%$ discount rate has minimum value $\$ 0.212 / \mathrm{kWh}$. Moreover, for each discount rate the minimum LCOE will be observed with $0 \%$ interest rate, for example, the LCOE for the hybrid system when the discount rate is $5 \%$ is $\$ 0.229 / \mathrm{kWh}$ (25 year loan term); when discount rate is $3 \%$ is $\$ 0.223 / \mathrm{kWh}$ (25 years loan term).

Figure 5A-C shows how the LCOE of the system varying as a function of the capital cost of the PV and CHP with capital cost of battery held constant. The discount rate for this case is $3 \%, 2 \%$ interest rate, 25 years loan term, whereas this will affect the operation and maintenance cost of the PV module. In Figure 5A-C, the capital cost of the CHP module is $\$ 1,400 / \mathrm{kW}, \$ 1,000 / \mathrm{kW}$ and $\$ 500 / \mathrm{kW}$ respectively, whereas the installation cost of $\mathrm{PV}$ module is varied from $\$ 0.50 / \mathrm{W}$ to $\$ 4.00 / \mathrm{W}$ for each case. It can be seen that the LCOE is obtained with installation cost of PV at $\$ 0.50 / \mathrm{W}$ and capital cost of $\mathrm{CHP}$ is $\$ 500 / \mathrm{W}$ is $\$ 0.063 / \mathrm{kWh}$. The capital cost of the modules plays an important role in LCOE of the hybrid system, whereas a small change in capital cost of the CHP module does not change the LCOE of the system by large values. For example when installation cost of the PV subsystem is $\$ 1.00 / \mathrm{W}$ with the capital cost of CHP of $\$ 1,400 / \mathrm{kW}$, the LCOE of the hybrid system is $\$ 0.086 / \mathrm{kWh}$ (25years), however, when the capital cost of CHP module is $\$ 1,000 / \mathrm{kW}$ the LCOE of the hybrid system is $\$ 0.085 / \mathrm{kWh}$. Furthermore, if the capital cost of the battery is reduced with minimum capital cost of CHP module and installation cost of PV module the LCOE value can be reduced more. Figure 3D gives 
Preprint: Aishwarya Mundada, Kunal Shah, Joshua M. Pearce. Levelized cost of electricity for solar photovoltaic, battery and cogen hybrid systems, Renewable and Sustainable Energy Reviews 57, (2016), 692-703.

the LCOE of the system with installation cost of PV at $\$ 0.50 / \mathrm{W}$ and the capital cost of CHP $\$ 500 / \mathrm{kW}$ and varying capital cost of battery sub-system between $\$ 1,000$ and $\$ 250$, respectively. Note, that this capital costs change also effects the battery replacement cost. It can be seen that the LCOE of the hybrid system is $\$ 0.053 / \mathrm{kWh}$ and is obtained when installation cost of CHP module is $\$ 500 / \mathrm{kW}$, whereas the capital cost of PV module and battery is $\$ 0.50 / \mathrm{W}$ and $\$ 500$ respectively. With the battery cost declining by another $50 \%$, the LCOE declines by another approximately 2 cents per kWh.

Figure 6 shows how the LCOE of the system is affected by change in the capacity factor of the PV and the CHP sub-systems. As already mentioned, by minimizing the capacity factor of the CHP sub-system the LCOE of the complete system can be reduced. The capacity factor of the PV and CHP will affect the rated energy generated by each other. The total energy out of the system is the energy contribution of PV and the CHP sub-systems. If the capacity factor of the PV module is increased this will increase the rated energy output of the PV and will reduce the contribution by the CHP. The capacity factor of the PV module is varied 13\%, 15.3\% and 18\% and the resultant CHP capacity factor is summarized in Table 6. For this case the discount rate is $3 \%$ and interest rate is $2 \%$ with 25 years loan term and the results are shown in Figure 6. It can be observed that we get minimum LCOE $\$ 0.225 / \mathrm{kWh}$ when capacity factor of PV module is $18 \%$ and CHP module is $14.32 \%$.

Figure 7 shows how the LCOE of the system is affected by the change in the efficiency of the CHP module. The change in the efficiency also impacts the fuel consumption of the CHP module and hence the total cost of fuel. The efficiency of the CHP is varied from $85 \%$ to $98 \%$ and all other factors are kept unchanged. As the efficiency increases the total fuel cost is reduced and thus the LCOE of the system. For example the LCOE of the system is $\$ 0.239 / \mathrm{kWh}$ for $90 \%$ efficient CHP and is $\$ 0.241 / \mathrm{kWh}$ for $85 \%$ efficient CHP module. The minimum LCOE $\$ 0.237 / \mathrm{kWh}$ is obtained when the efficiency is maximum $98 \%$ (25 years).

Figure 8 shows how the LCOE of the hybrid system varies with change in rates of natural gas (\$/MMBTU). As can be seen from Table 3 the natural gas rates have varied historically and is difficult to predict into the future so a sensitivity analysis on natural gas rates was performed to investigate the effects on the LCOE of the hybrid system. The natural gas rates are varied from \$6/MMBTU to \$15/MMBTU and LCOE of the system has been determined. From the results summarized in Figure 8 it is clear that the natural gas rates have a muted effect the LCOE rates of the system. For example the LCOE is $\$ 0.258 / \mathrm{kWh}$ when natural gas rates are $\$ 15 / \mathrm{MMBTU}$, whereas it is only 2 cents less $(\$ 0.232 / \mathrm{kWh})$ when natural gas rates are reduced by nearly a factor of three to $\$ 6 / \mathrm{MMBTU}$.

\section{5) Discussion}

A simple methodology for calculation of LCOE of hybrid PV, battery and CHP system has been presented. The methodology was used to determine the LCOE for the hybrid system which can be installed in Houghton, Michigan, US. The results of the case study are present in Figures 3-8, which provide a quantitative view of the effects on the LCOE with changes in various input factors.

The high initial installation cost of the hybrid system can be an obstacle in its installation in this region with an immature market for both PV and CHP systems. However, it can be observed that with lower interest rates, long term loans, high discount rate and a reasonable degradation rate, such a system will be profitable and may be preferred to maintaining grid dependence. It can be seen from Figure 5A-C that the LCOE of the system was greatly affected by the installation cost of PV and the 
Preprint: Aishwarya Mundada, Kunal Shah, Joshua M. Pearce. Levelized cost of electricity for solar photovoltaic, battery and cogen hybrid systems, Renewable and Sustainable Energy Reviews 57, (2016), 692-703.

capital cost of the CHP. The largest contributions of the PV subsystem costs are the PV module cost and the inverter cost, although it is clear in comparison with regions with more mature markets that if the BOS cost is reduced then the installation cost of PV module can be significantly further reduced. Moreover, Figure 5D shows with the reduction in the battery cost the LCOE of the system can further be reduced, but the cost of the battery has a relatively small impact on the LCOE for the entire system.

The interest rates and discount rates also affects the LCOE of the system. This can be seen by comparing the results in Figure 4A-4F. When both of these financing terms are high the impact is severe and raises the LCOE outside of the range of profitability. Using current low interest rates result in a competitive LCOE even with inflated initial costs. Figure $4 \mathrm{~A}$ shows $0 \%$ interest rate with long loan term results into lowest LCOE value for any given starting condition.

The capacity factor of the PV as well as CHP also affects the LCOE of the system. This can be seen from Figure 6. As the capacity factor of PV increases the energy generated at the output of the PV also increases. The total energy at the output of the system is maintained constant so as it is sufficient to satisfy the electrical load demand of the house, and thus the energy at the output of the CHP can be reduced by reducing the capacity factor of the CHP. As the capacity factor of the CHP declines the number of hours the CHP module operates in a year is reduced resulting in less fuel consumption and improving the LCOE of the hybrid system. As can be seen in Figure 6 this effect is relatively minor.

The efficiency of the CHP was also varied between $75 \%$ to $98 \%$. As the efficiency of the CHP increases the fuel consumption is reduced, reducing the fuel cost and improving the LCOE as can be seen in Figure 7. As CHP units are already relatively efficient the relative impact on the LCOE is a minor one.

Although in recent years in the U.S. as a whole (and in the case study region of MI in particular) the natural gas retail prices have been declining as seen in Table 3, the natural gas rates can even increase or decrease over the next 25years. Thus, the cost of the fuel utilized by the CHP will be affected, and hence the LCOE of the system. The impact of natural gas prices on the hybrid system can be seen in Figure 8. Lowering the natural gas rates reduces the LCOE of the system, but large changes in the fuel costs have relatively minor impacts on the LCOE of the whole system.

The results of both the initial case study (Figure 4) in Houghton, MI and the sensitivity (Figures 5-8) provide decision makers with clear guides to the LCOE of distributed generation with off-grid PV+battery+CHP systems. The lower LCOE costs of the hybrid off-grid system (Figures 4-8) as compared to grid costs with even modest escalation rates (Figure 3) offer support to preliminary analysis that indicated a potential increase in grid defection in the U.S. in the near future [94].

\section{Limitations and Future Work}

It should be pointed out here that Houghton should not be considered representative of the U.S. in any way. It has both more severe winters (and thus higher heating costs and less solar flux) than most of the rest of the U.S. In addition, Houghton electric rates are particularly high for the U.S. because of the geographic (and thus grid) isolation in the upper peninsula of Michigan and the miningcentric nature of the electric loads. However, some of the same circumstances that drive higher utility rates also increase the installed cost of PV as compared to the U.S. national average. Thus this case study should only be considered as an example of the methodology and future work is needed to 
Preprint: Aishwarya Mundada, Kunal Shah, Joshua M. Pearce. Levelized cost of electricity for solar photovoltaic, battery and cogen hybrid systems, Renewable and Sustainable Energy Reviews 57, (2016), 692-703.

evaluate representative locations in each region of the country as demarcated by solar flux, natural gas prices and electricity prices.

This study focused on the LCOE and thus the cost of electricity from a hybrid system. The analysis is inherently conservative as it does not include the additional value of the heat form the CHP unit. However, the thermal demand that will be satisfied by the CHP module in the hybrid system is 18 MMBTU/year (i.e. $20 \%$ of the total annual demand in the case study region). The remaining $80 \%$ is to be satisfied with a conventional heater or furnace unit. The natural gas utilized by the heater and its corresponding cost can be taken into account and can be considered for future work for a complete economic analysis of such hybrid systems. In addition, future work could investigate modeling larger CHP systems to satisfy not only the electrical demand, but also the thermal demand of a residential building. Such systems may be viable in locations that do not have as extreme of winters as the case study region.

The CHP project, while not free of greenhouse gas emissions, is a least cost option to back up the PV system that also offers a reduction of approximately $60 \%$ in source energy and carbon versus a coal plant and creates approximately as many jobs as a wind or solar project of similar capacity [42]. CHP offers reductions in total primary fuel consumption on the order of $30 \%$ to $35 \%$, which means equivalent $\mathrm{CO}_{2}$ emissions reduction if the same fuel is consumed [42]. Thus, to further improve the work done the GHG emission rates can be considered.

An absorption chiller can be added to the CHP output to utilize the maximum amount heat energy available, thus raising the efficiency further. Such systems are known as trigeneration systems or CCHP (combined cooling heating and power) and have been investigated technically and appear promising [95-99]. Tri-generation being one of the most promising technologies allows the efficient simultaneous production of heat, cooling and power with all the three potential benefits technical, economic and environmental [100]. Future works is needed to couple the cost of cooling into a complete life cycle cost analysis of such complex systems over a range of geographical locations and local climates.

It should be noted that although this case study was for the U.S., the details of the hybrid system economics reviewed in this study are valid elsewhere. The primary differences between the systems would be ensuring they meet the standards of the local regulators. For example, in Europe the guidelines set forth by EURELECTRIC, may influence dispatch strategies [101].

Historically, the quantity of output power from the distributed generation sources was restricted by the local demand load; however now bi-directional power flow between distribution system and transmission systems can be used due to new system structures allowing distributed grid to export power when local generation exceeds the consumption [102-104]. This has resulted in higher complexity in the management of distribution systems and thus the skills of the electrical engineers responsible for the grid. At the same time it has offered new possibilities to optimize the overall system by allowing distribution networks and distributed renewable energy to participate actively in the system operation [105]. It should be noted that in some parts of Europe, particularly in the southern region of Germany the output from distributed generation technologies on distribution networks is already exceeding the local load demand [106-104]. As distributed renewable energy matures throughout the world, this could be the new normal rather than the exception.

In addition, optimizing such hybrid systems for GHG emission reductions can be considered in the future using dynamic life cycle analysis that reduced life-cycle carbon emissions [107]. One way to 
Preprint: Aishwarya Mundada, Kunal Shah, Joshua M. Pearce. Levelized cost of electricity for solar photovoltaic, battery and cogen hybrid systems, Renewable and Sustainable Energy Reviews 57, (2016), 692-703.

do this is with biomass-fueled CHP systems, which can produce heat and power with reduced net GHG emissions, and thus can be much more climate-friendly than systems fueled with fossil natural gas, coal, or oil. Biomass can be considered as renewable with low carbon emission and increasingly cost competitive alternative to traditional fossil fuels for heat and/or electric power generation [108]. By substituting biomass for fossil fuel, carbon emissions from non-renewable, fossil fuels can be avoided [41]. Finally, in some areas it may be possible to use a solar-only trigeneration systems for even more aggressive GHG emission cuts [109]. Again, further work is needed to provide a complete economic analysis of these types of systems.

\section{Conclusions}

A new method to calculate the LCOE of a complex PV+battery+CHP system was presented. A case study for residential electricity and thermal demand in an extreme worst case environment (Houghton, Michigan) showed that with reasonable economic assumptions and current costs such offgrid hybrid systems already provide a potential source of profit for grid defectors. A sensitivity analysis for LCOE of such a hybrid systems on the capital cost of the three energy sub-systems, capacity factor of PV and CHP, efficiency of the CHP, natural gas rates, and fuel consumption of the CHP provide decision makers with clear guides to the LCOE of distributed generation with off-grid PV+battery+CHP systems. The most important factors for determining LCOE of hybrid system are system cost, financing, operation and maintenance cost, fuel cost, loan-term and lifetime. With favorable financing terms, declining of the initial system cost due to advancement in the technology, and grid electricity rate escalation such a hybrid system can become an economically advantageous source for fulfilling the electricity demand along with contributing for the thermal demand of the residential units throughout a wide collections of geographic locations. The results offer support to the preliminary analysis that indicated a potential increase in grid defection in the U.S. in the near future as it is clear that PV+battery+CHP is already economically feasible in some locations and as markets for the distributed generation technologies continue to mature economics without subsidies will provide incentives for grid defection and assist in increasing PV penetration levels in the U.S.

\section{References}

[1] Honeyman C, Kimbis T. U.S.Solar Market Insight Report Q2 2014-Executive Summary. Greentech Media, Inc. and Solar Energy Industries Association, 2014. Washington D.C.

[2] Branker K, Pearce J.M. Financial Return for Government Support of Large-Scale Thin-Film Solar Photovoltaic Manufacturing in Canada. Energy Policy 2010; 38, pp. 4291-4303.

[3] U.S. Solar Market Insight: 2010 Year-in-Review-Executive Summary. Greentech Media, Inc. and Solar Energy Industries Association, 2010. Washington, D.C.

[4] Linder S, Capua M.D. Re-imagining US Solar Financing. US Solar - White Paper. Bloomberg New Energy Finance. 4 June 2012. 
Preprint: Aishwarya Mundada, Kunal Shah, Joshua M. Pearce. Levelized cost of electricity for solar photovoltaic, battery and cogen hybrid systems, Renewable and Sustainable Energy Reviews 57, (2016), 692-703.

[5] Sherwood L. U.S. Solar Market Trends-2011. Interstate Renewable Energy Council. August 2012. Available at: <http://www.irecusa.org/wp-content/uploads/IRECSolarMarketTrends-2012-Web-8-2812.pdf $>$.

[6] Feldman D, Barbose G, Margolis R, Wiser R, Darghouth N, Goodrich A. Photovoltaic (PV) Pricing Trends: Historical, Recent, and Near-Term Projections. Sunshot- U.S. Department of Energy. Nov 2012. Technical Report DOE/GO-102012-3839

[7] Honeyman C, Kimbis T. U.S.Solar Market Insight Report Q1 2014-Executive Summary. Greentech Media, Inc. and Solar Energy Industries Association, 2014. Washington D.C.

[8] Pearce J.M. Photovoltaics - a path to sustainable futures. Futures 2002; 34(7), pp. 663-674(12).

[9] Prindle B., Eldridge M., Eckhardt M., Frederick A. The Twin Pillars of Sustainable Energy: Synergies between Energy Efficiency and Renewable Energy Technology and Policy. American Council for an Energy-Efficient Economy 2007; Report number: E074.

[10] Timilsina G.R., Kurdgelashvili L., Narbel P.A. Solar energy: Markets, economics and policies. Renew. Sustainable Energy Rev 2012; 16, 449-465.

[11] Pathak M. J. M., Sanders P. G., Pearce J. M. Optimizing limited solar roof access by exergy analysis of solar thermal, photovoltaic, and hybrid photovoltaic thermal systems. Appl Energy 2014; $120,115-124$.

[12] Branker K., Pathak M.J.M, Pearce J.M. A Review of Solar Photovoltaic Levelized Cost of Electricity. Renew. Sustainable Energy Rev 2011, 15, 4470-4482.

[13] Morgan B, Onyeji I, Liebreich M, MacGill I, Chase J, Shah J, Gielen D, Arent D, Landfear D, Zhengrong S. Re-considering the economics of photovoltaic power. Renew. Energy 2013; 53, 329-338.

[14] McDonald, A., \& Schrattenholzer, LLearning rates for energy technologies. Energy policy 2001; 29(4), 255-261.

[15] Van der Zwaan B., Rabl, A. Prospects for PV: a learning curve analysis. Solar Energy 2003; 74(1), 19-31.

[16] Watanabe C., Nagamatsu A., Griffy-Brown, C. Behavior of technology in reducing prices of innovative goods - an analysis of the governing factors of variance of PV module prices. Technovation 2003; 23(5), 423-436.

[17] Nemet G. F. Beyond the learning curve: factors influencing cost reductions in photovoltaics. Energy Policy 2006; 34(17), 3218-3232.

[18] Chiara C, Winskel M, Gross R.J.K. The dynamics of solar PV costs and prices as a challenge for technology forecasting. Renew. Sustainable Energy Rev 2013; 26, 96-107.

[19] Barbose G., Darghouth N. R., Weaver S., Feldman D., Margolis R., and Wiser R. Tracking US photovoltaic system prices 1998-2012: a rapidly changing market. Prog. Photovolt: Res. Appl. 2015;23, 692-704. doi: 10.1002/pip.2482.

[20] Breyer C. and Gerlach A. Global overview on grid-parity. Prog. Photovolt: Res. Appl.2013; 21: 121-136. doi: 10.1002/pip.1254

[21] Reichelstein S, and Michael Y. The prospects for cost competitive solar PV power. Energy Policy 2013; $55: 117-127$. 
Preprint: Aishwarya Mundada, Kunal Shah, Joshua M. Pearce. Levelized cost of electricity for solar photovoltaic, battery and cogen hybrid systems, Renewable and Sustainable Energy Reviews 57, (2016), 692-703.

[22] Passera L. Colorado PUC keeps net metering in place for now. Interstate Renewable Energy council .February 12 2014. Available at :<http://www.irecusa.org/2014/02/colorado-puc-keeps-netmetering-in-place-for-now/>

[23] Kansas State Committee on Energy and Environment. Kansas House Bill 2458. 2014. Available at: 〈http://www.kslegislature.org/li/b2013 14/measures/documents/hb2458 00 0000.pdf>

[24] Montgomery J. Net-Metering in 2014: Where the first battles will be fought. Renewable Energy World. Jan 29 2014. Available at:

<http://www.renewableenergyworld.com/rea/news/print/article/2014/01/net-metering-in-2014-wherethe-first-battles-will-be-fought>

[25] Elsner G. Dominion Virginia block net metering bill. Energy and Policy Institute. Feb 62014. Available at:

<http://www.energyandpolicy.org/dominion_thwarts_solar_net_metering_bill_in_virginia>

[26] Barnes J, Culley T, Haynes R, Passera L, Wiedman J. Best Practices in State Net Metering and Interconnection Procedures, Freeing the Grid. Interstate Renewable Energy Council. Nov 2013

[27] Cocke S. HECO: 80 percent of circuits on Oahu have room for solar. CivilBeat. Oct 222013. Available at: <http://www.civilbeat.com/2013/10/20211-fact-check-heco-80-percent-of-circuits-onoahu-have-room-for-solar/

[28] Martin C. Arizona Approves Grid-Connection Fees for Solar Rooftops. Bloomberg Business. Nov 15 2013. Available at <http://www.bloomberg.com/news/2013-11-15/arizona-regulators-impose-powergrid-fees-for-solar-roofs.html >

[29] Henry R. PSC Staff recommends against Georgia Power solar fee. OnlineAthens. Oct 182013. Available at : $\backslash$ http://onlineathens.com/local-news/2013-10-18/psc-staff-recommends-against-georgiapower-solar-fee

[30] Passera L. Idaho PSC improves net metering rules for Idaho Power. Interstate Renewable Energy Council. July 10 2013. Available at : 〈http://www.irecusa.org/2013/07/idaho-psc-improves-net-meteringrules-for-idaho-power/

[31] Martin C. NRDC and U.S. Utilities Urge Grid Payments for Rooftop Solar. Renewable Energy world. Feb 13 2014. Available at: http://www.renewableenergyworld.com/rea/news/article/2014/02/nrdcand-u-s-utilities-urge-grid-payments-for-rooftop-solar

[32] Passera L. Utah Utility proposes additional net metering fee. Interstate Renewable Energy Council. Jan 13 2014. Available at: http://www.irecusa.org/2014/01/utah-utility-proposes-additional-netmetering-fee/

[33] Sterzinger G.J. 1981. The Customer Charge and Problems of Double Allocation of Costs, Public. Utilities Fortnightly, July 2 1981; pp. 30-32.

[34] Kaufmann K. Utilities seek electric rate increases. The Desert Sun. 22 April 2014. Available at: http://www.desertsun.com/story/money/business/2014/04/22/rooftop-solar-southern-california-edisonutilities-seek-electric-rate-increases/7995093/ 
Preprint: Aishwarya Mundada, Kunal Shah, Joshua M. Pearce. Levelized cost of electricity for solar photovoltaic, battery and cogen hybrid systems, Renewable and Sustainable Energy Reviews 57, (2016), 692-703.

[35] Daniels S. Chicago electric bills to rise up to $18 \%$ in June under new Integrys deal. CRAINS's Chicago Business. March 9 2014. Available at:

http://www.chicagobusiness.com/article/20140309/NEWS11/140309785/chicago-electric-bills-to-riseup-to-18-in-june-under-new-integrys-deal

[36] Gallucci M. Ohio Gov. Kasich to Sign "Freeze" On State Clean Energy Mandate By Saturday. International Business Times. June 11 2014. Available at: www.ibtimes.com/ohio-gov-kasich-signfreeze-state-clean-energy-mandate-saturday-1598602

[37] Gyuk I, Johnson M, Vetrano J, Lynn K, Parks W, Handa R, Kannberg L, Hearne S, Waldrip K, Braccio R. Grid Energy Storage. U.S. Department of Energy. December 2013.

[38] Planned 2020 Gigafactory Production Exceeds 2013 Global Production. Tesla, 2014. Avaialble at: http://www.teslamotors.com/sites/default/files/blog attachments/gigafactory.pdf

[39] Public Utility Regulatory Policies Act (PURPA) 1978. Nov 19 1978. Available at: http://www.usbr.gov/power/legislation/purpa.pdf

[40] Combined Heat and Power (CHP). American Council for an Energy-Efficient-Economy. Washington D.C. Aug 2009. Available at: < http://aceee.org/topics/combined-heat-and-power-chp [41]Fact Sheet: Combined Heat and Power: Pathway to Lower Energy Costs, Reduced Emissions, Secure and Resilient Energy Supply . May 2013. Environment and Energy study Institute.

[42] Quinn J, James F, Whitaker C. Combined Heat \& Power, 2013: Are We There Yet? American Council for an Energy-Efficient-Economy-Summer Study on Energy Efficiency in Industry.

[43] Darrow K, Tidball R, Wang J, Hampson A. Catalog of CHP Technologies. U.S. Environmental Protection Agency Combined Heat and Power Partnership, March 2015.

[44] Nguyen T, Spendelow J, Margolis R. Levelized Costs of Electricity from CHP and PV. Department of Energy. Program Record (Office of Solar Energy Technologies \&Fuel cell Technologies). February 27, 2014. Record\#:14003

[45] ] Olson A, Schlag N, Patel K, Kwok G. Capital cost Review of Power Generation Technologies.. Prepared for the Western Electric Coordinating Council. March 2014.

[46] Natural gas rates. U.S. Energy Information Administartion. Available at:

<http://www.eia.gov/dnav/ng/ng pri sum dcu SMI a.htm

[47] Guccione L, Bronski P. Will the Electricity Grid Become Optional? Rocky Mountain Institute (RMI). Feb 25 2014. Available at:

http://blog.rmi.org/blog_2014_02_25_will_the_electricity_grid_become_optional

[48]Shah K.K, Mundada A.S, Pearce J.M. Performance Analysis of Solar Photovoltaic, Battery and Combined Heat and Power Hybrid. Energy Convers. Manage., 2015; 105 (2015) 71-80. 
Preprint: Aishwarya Mundada, Kunal Shah, Joshua M. Pearce. Levelized cost of electricity for solar photovoltaic, battery and cogen hybrid systems, Renewable and Sustainable Energy Reviews 57, (2016), 692-703.

[49] Helal A, Ghoneim W, Halaby A. Feasibility study for self-sustained wastewater treatment plantsusing biogas CHP fuel cell, micro-turbine, PV and wind turbine systems. Smart Grid Renew Energy, 2013; 4:227-35.

[50] Maghanki MM, Ghobadian B, Najafi G, Galogah RJ. Micro combined heat and power (MCHP) technologies and applications. Renew Sustain Energy Rev, 2013; 28:510-24.

[51] Bando S, Asano H, Tokumoto T, Tsukada T, Ogata T. Optimal operation planning of a photovoltaic-cogeneration-battery hybrid system. In: International Conference on Power System Technology. PowerCon. Institute of Electrical and Electronics Engineer; 2006, p. 1-8.

[52] Green HJ, Manwell J. HYBRID2: A versatile model for the performance of hybrid systems. Report by National Renewable Energy Laboratory; 1992.

[53] Carmeli MS, Castelli-Dezza F, Marchegiani G, Mauri M, Piegari L, Rosati D. Hybrid PV-CHP distributed system: design aspects and realization. In: 2009 International conference on clean electrical power. IEEE; 2009. p. 782-9.

[54] Short W, Packey D.J, Holt T. A Manual for the Economic Evaluation of Energy Efficiency and Renewable Energy Technologies. National Renewable Energy Laboratory, NREL/TP-462-5173. March 1995.

[55] Darling S.B., You F., Veselka T., Velosa A. Assumptions and the levelized cost of energy for photovoltaics, Energy Environ. Sci.,2011; 7 pages (Advance Article)

[56] Velosa III A. What is inside LCOE Assumptions? Semi PV. April 2010.

[57]Grana P. Demystifying LCOE. RenewableEnergyWorld.com, August 18, 2010, Available at: http://www.renewableenergyworld.com/rea/blog/post/2010/08/demystifyinglcoe

[58] Larsson S., Fantazzini D., Davidsson S., Kullander S., Höök M. Renew. Sustainable Energy Rev., $2014 ; 30,170-183$.

[59] Chandler H, Nguyen F., Remme, U. Projected Costs of Generating Electricity-Edition 2010. International Energy Agency, Nuclear Energy Agency, Organization for Economic Co-operation and Development; 2010.

[60] Biomass for Power generation. Renewable Energy Technologies: Cost Analysis series-Volume 1: Power Sector Issue 5/5. International Renewable Energy Agency, June 2012.

[61] Abdelhady S., Borello D., Tortora E. Design of a small scale stand-alone solar thermal cogeneration plant for an isolated region in Egypt. Energy Convers. Manage., 2014; 88, 872-882.

[62] Frangopoulos C.A. A method to determine the power to heat ratio, the cogenerated electricity and the primary energy savings of cogeneration systems. Energy, 2012; 45, 52-61. 
Preprint: Aishwarya Mundada, Kunal Shah, Joshua M. Pearce. Levelized cost of electricity for solar photovoltaic, battery and cogen hybrid systems, Renewable and Sustainable Energy Reviews 57, (2016), 692-703.

[63] Methods for Calculating Efficiency. U.S. Environmental Protection Agency. Available at: http://www3.epa.gov/chp/basic/methods.html

[64] Kolwey N. Calculating Net Electricity Savings from Utility-Supported CHP Projects. Southwest Energy Efficiency Project; April 2013.

[65] Rushing A.S, Kneifel J.D., Lippiatt B.C. Energy Price Indices and Discount Factors for LifeCycle Cost Analysis - 2013 Annual Supplement to NIST Handbook 135 and NBS Special Publication 709. National Institute of Standard and Technology, U.S. Department of Commerce, 2013; NISTIR 853273-28.

[66] Mercom Capital Group. Solar market intelligence report; 4 October 2010. p.1-9.

[67] Barbose G., Darghouth N.R., Weaver S., Wiser R.H. Tracking the Sun: An Historical Summary of the Installed Price of Photovoltaics in the United States from 1998 to 2012. Report by Sunshot: LBNL6350E DOE. July 2013.

[68] Barbose G., Darghouth N.R., Wiser R.H. Tracking the Sun III, the installed cost of photovoltaics in the U.S. from 1998-2009. US Department of Energy, Lawrence Berkley National Laboratory; 2010. p. 1-54.

[69] Bony L, Doig S, Hart C, Maurer E, Newman S. Achieving low-cost solar PV: industry workshop recommendations for near-term balance of system cost reductions. Rocky Mountain Institute (RMI); 2010. p. 1-24.

[70] Pearce JM. Industrial symbiosis for very large scale photovoltaic manufacturing. Renew. Energy, 2008; 33:1101-8.

[71] VLSI Research Inc. Photovoltaic cell manufacturing equipment: top- 10 supplier ranking [accessed 20.02.2009]. Bedford, England. Feb 22009.

[72] Yang C. Reconsidering solar grid parity. Energy Policy 2010; 38:3270-3.

[73] Feldman D., Boff D., Margolis R. National Survey Report of PV Power Applications in the United States 2013. Photovoltaic Power Systems Programme. Sunshot, DOE and International Energy Agency. 2013.

[74] Honeyman C, Kimbis T. U.S.Solar Market Insight Report Q4 2014-Executive Summary. Greentech Media, Inc. and Solar Energy Industries Association, 2014. Washington D.C. 
Preprint: Aishwarya Mundada, Kunal Shah, Joshua M. Pearce. Levelized cost of electricity for solar photovoltaic, battery and cogen hybrid systems, Renewable and Sustainable Energy Reviews 57, (2016), 692-703.

[75] Solar Panels - Price Survey. Available at: <http://www.ecobusinesslinks.com/surveys/free-solarpanelprice-survey/>

[76] Calhoun K, Morris J. Can the Cost of Solar in the U.S. Compete with Germany? Report by Rocky Mountain Institute (RMI). Dec 52013.

[77] Catalog of CHP Technologies. U.S. Environmental Protection Agency, Combined Heat and Power Partnership. March 2015

[78] Wit J.D, Näslund M. Mini and Micro Cogenration. Danish Gas Technology Centre.

[79] Solar Ray: Deep Cycle Batteries Available at: <http://solarray.com/TechGuides/Batteries_T.php

[80] Belluardo G., Ingenhoven P., Moser D. Medium Term Degradation of different Photovoltaic Technologies under outdoor conditions in Alpine Area.

[81] Jordan D.C, Smith R.M., Osterwald C.R., Gelak E., Kurtz S.R. Outdoor PV Degradation Comparison. National renewable Energy Laboratory, February 2011; NREL/CP-5200-47704.

[82] Commercial and Residential hourly load profile. Open Data Catlog. U.S. Department of Energy. Available at: <http://en.openei.org/doe-opendata/dataset/commercial-and-residential-hourly-loadprofiles-for-all-tmy3-locations-in-the-united-states/resource/b341f6c6-ab5a-4976-bd07-adc68a2239c4>

[83] Energy Use in Michigan. Residential Energy Consumption Survey. U.S. Energy Information Administration, 2009.

[84] CHP Technologies. Presented by Midwest CHP Application center. University of Illinois Chicago, Energy Resource Center Available at: <http://www.midwestchptap.org/Archive/presentations/021107MN/021107-2A.pdf>

[85] Review of Combined Heat and Powder Technologies 1999. U.S. Department of Energy. Report by ONSITE SYCOM Energy Corporation, Oct 1999.

[86] Kweight storage and backup battery, Solar storage gel battery 2v 1200ah specification sheet. Available at: http://www.alibaba.com/product-detail/Solar-storage-gel-battery-2v1200ah_60249506072.html?spm=a2700.7724857.35.1.0607un

[87] Deep cycle Batteries for Offgrid and Remote Power system. Available at: <http://www.solarwind.co.uk/deep-cycle-dryfit-batteries-battery-uk.html> 
Preprint: Aishwarya Mundada, Kunal Shah, Joshua M. Pearce. Levelized cost of electricity for solar photovoltaic, battery and cogen hybrid systems, Renewable and Sustainable Energy Reviews 57, (2016), 692-703.

[88] Simader G.R, Krawinkler R., Trnka G. Micro CHP systems: state-of-the-art. Austrian Energy agency, Deliverable 8 (D8) of Green Lodges Project (EIE/04/252/S07.38608). Vienna, March 2006.

[89] Ecopower MicroCHP Specification datasheet.

Available at: http://www.marathonengine.com/downloads/Ecopower_Brochure_2014opt.pdf

[90] Tanaka H., Suzuki A., Yamamoto K., Yamamoto I., Yoshimura M., Togawa K. NEW ECOWILL A NEW GENERATION GAS. International Gas Union Research Conference 2011.

[91] Yanmar microchip system specification sheet. Available at:

<http://sonicchp.com/themes/sonicchp/docs/5kw-yanmar-data-sheet.pdf $>$

[92] Kantamneni A. Houghton Residents pay highest electric rates in Michigan. UPEDA Energy Series.

[93] Bronski P., Creyts J., Guccione L., Madrazo M., Mandel J., \& Rader B. The economics of grid defection: When and where distributed solar generation plus storage competes with traditional utility service. Rocky Mountain Institute, HOMER Energy, Cohn and Reznick-Think Energy, 2014.

[94] Levelized Cost of Energy Calculator. National Renewable Energy Lab. Available at: http://www.nrel.gov/analysis/tech_lcoe.html

[95] Pearce. J.M. Expanding photovoltaic penetration with residential distributed generation from hybrid solar photovoltaic and combined heat and power systems. Energy, 2009; 34(11), 1947-1954.

[96] Nosrat A., \& Pearce J. M. Dispatch strategy and model for hybrid photovoltaic and trigeneration power systems. Applied Energy, 2011; 88(9), 3270-3276.

[97] Li X., \& Ogden, J. M. Pearce. Understanding the design and economics of distributed trigeneration systems for home and neighborhood refueling-Part I: Single family residence case studies. Power Sources, 2011; 196(4), 2098-2108.

[98] Nosrat A. H., Swan L. G., \& Pearce J. M. Improved performance of hybrid photovoltaictrigeneration systems over photovoltaic-cogen systems including effects of battery storage. Energy, 2013; 49, 366-374.

[99] Nosrat A. H., Swan L. G., \& Pearce J. M. Simulations of greenhouse gas emission reductions from low-cost hybrid solar photovoltaic and cogeneration systems for new communities. Sustainable Energy Technologies and Assessments, 2014; 8, 34-41.

[100] Jradi M, Riffat S. Tri-generation systems:Energy policies,prime movers,cooling technologies,configurations and operationstrategies. 2014. Renew. Sustainable Energy Rev., 2014; 32, 396-415. 
Preprint: Aishwarya Mundada, Kunal Shah, Joshua M. Pearce. Levelized cost of electricity for solar photovoltaic, battery and cogen hybrid systems, Renewable and Sustainable Energy Reviews 57, (2016), 692-703.

[101] Pierre I, Achermann H, Arias A, Janikowski J; Leber F, Mousa F, Opdenacker P, Schilcher H, The role of CHP in the proposed Energy Efficiency Directive (COM(2011) 370 Final). A EURELECTRIC policy paper. Dépôt légal: D/2011/12.205/14, Kohopaa A. October-2011.

[102] L'Abbate A, Fulli G, Starr F, Peteves S.D. Distributed Power Generation in Europe: technical issues for further integration. JRC Scientific and Technical report, 2007.

[103] European Smartgrid Technology Platform-Vision and Strategy for Europe's Electricity Networks of the Future. Directorate-General for Research Sustainable Energy Systems. Luxembourg: Office for Official Publications of the European Communities, 2006, ISBN 92-79-01414-5.

[104] Study on the effective integration of Distributed Energy Resources for providing flexibility to the electricity system. Final report to The European Commission by SWECO, 2015, Proj no: 54697590000.

[105] The Integrated Grid Realizing the Full value of Central and Distributed Energy Resources. Electric Power Research Institute, 2014.

[106] How is Germany integrating and balancing renewable energy today? Energy Transition-The German Energiewende, Feb 2015 Available at: http://energytransition.de/2015/02/how-germany-integratesrenewable-energy/

[107] Kenny R., Law C., \& Pearce J. M. Towards real energy economics: energy policy driven by lifecycle carbon emission. Energy Policy, 2010; 38(4), 1969-1978.

[108] Salomón M, Savol T, Martin A, Fogelholmb C.J, Fransson T. Small-scale biomass CHP plants in Sweden and Finland. Renew. Sustainable Energy Rev., 2011; 15, 4451- 4465.

[109] Magalhães P., Martins J., Joyce A., Coelho L., Tavares N., \& Pereira R. Solar Trigeneration System Model for Off-Grid Residential Applications. In Technological Innovation for Value Creation, Springer Berlin Heidelberg, 2012; pp. 375-384. 
Preprint: Aishwarya Mundada, Kunal Shah, Joshua M. Pearce. Levelized cost of electricity for solar photovoltaic, battery and cogen hybrid systems, Renewable and Sustainable Energy Reviews 57, (2016), 692-703.

\section{Tables}

Table 1: Summary of Average Residential PV Installed System Costs [67,73,74].

\begin{tabular}{|l|l|l|}
\hline Solar PV Installation year & $\begin{array}{l}\text { Size of the system } \\
(\mathbf{k W})\end{array}$ & Installed Cost(\$/W) \\
\hline 2012 (US)* & $2-5$ & 5.2 \\
\hline 2012 (Germany)* & $2-5$ & 2.6 \\
\hline 2012 (Australia)* & $<5$ & 3.1 \\
\hline 2012 (Italy)* & $2-3$ & 3.1 \\
\hline 2012 (France)* & $<3$ & 4.8 \\
\hline 2012 (Germany)** & $2-5$ & 2.3 \\
\hline 2012 (US)** & $2-5$ & 5 \\
\hline 2013 (US) & $<10$ & 4.72 \\
\hline $2014($ US) & $<10$ & 3.5 \\
\hline
\end{tabular}

*-Excluding Tax

**-Including Tax

Table 2 : Electrical output, efficiency and total system efficiency for various CHP product available in market for residential use[61].

\begin{tabular}{|l|l|l|l|l|}
\hline Product & Technology & $\begin{array}{l}\text { Electrical } \\
\text { output(kW) }\end{array}$ & $\begin{array}{l}\text { Electrical } \\
\text { Efficiency(\%) }\end{array}$ & $\begin{array}{l}\text { Total } \\
\text { Efficiency(\%) }\end{array}$ \\
\hline Baxi-cogen & Stirling & 1 & 15 & 91 \\
\hline Honda Eco-will & ICE & 1 & 26 & 92 \\
\hline PanasonicEne-farm & Fuel cell & 1 & 35 & 85 \\
\hline CFCL Blue-gen & Fuel cell & 1.5 & 60 & $<85$ \\
\hline
\end{tabular}


Preprint: Aishwarya Mundada, Kunal Shah, Joshua M. Pearce. Levelized cost of electricity for solar photovoltaic, battery and cogen hybrid systems, Renewable and Sustainable Energy Reviews 57, (2016), 692-703.

Table 3 : CHP capital, engineering cost and efficiency depending on the technology [77,68].

\begin{tabular}{|c|c|c|c|}
\hline $\begin{array}{l}\text { CHP technology } \\
\text { (prime-mover) }\end{array}$ & y Typical Capacity & Installed cost $\left(\$ / \mathbf{k} W_{e}\right)$ & Efficiency (\%) \\
\hline Gas Turbine & 500kWe-300MWe & $\begin{array}{l}1,200-3,300 \\
(5-40 \mathrm{MW})\end{array}$ & $66-71 \%$ \\
\hline Steam Turbine & 50kWe to several hundred MWe & $\$ 670-1,100$ & Nearly 80\% \\
\hline Microturbine & $\begin{array}{l}30 \mathrm{kWe} \text { to } 250 \mathrm{kWe} \text { with } \\
\text { multiple unit packages up to } \\
1,000 \mathrm{kWe}\end{array}$ & $2,500-4,300$ & $63-70 \%$ \\
\hline $\begin{array}{l}\text { Internal- } \\
\text { combustion engine }\end{array}$ & $\begin{array}{l}1 \text { kWe to } 10 \text { MWe in DG } \\
\text { applications }\end{array}$ & $1,500-2,900$ & $75-80 \%$ \\
\hline Fuel Cell & $5 \mathrm{kWe}$ to $2 \mathrm{MWe}$ & $5,000-6,500$ & $55-80 \%$ \\
\hline
\end{tabular}

e: Electrical output from the CHP module. 
Preprint: Aishwarya Mundada, Kunal Shah, Joshua M. Pearce. Levelized cost of electricity for solar photovoltaic, battery and cogen hybrid systems, Renewable and Sustainable Energy Reviews 57, (2016), 692-703.

Table 4 : Natural gas rates for various years in MI, US [46].

\begin{tabular}{|c|c|}
\hline Year & $\begin{array}{c}\text { Michigan state Natural gas rates } \\
\text { (\$/MMBTU) }\end{array}$ \\
\hline 2009 & 11.37 \\
\hline 2010 & 11.32 \\
\hline 2011 & 10.47 \\
\hline 2012 & 9.95 \\
\hline 2013 & 9.09 \\
\hline
\end{tabular}


Preprint: Aishwarya Mundada, Kunal Shah, Joshua M. Pearce. Levelized cost of electricity for solar photovoltaic, battery and cogen hybrid systems, Renewable and Sustainable Energy Reviews 57, (2016), 692-703.

Table 5 : Natural gas rates variation in year 2014 for MI, US [46].

\begin{tabular}{|c|c|}
\hline $\begin{array}{c}\text { Month year- } \\
\mathbf{2 0 1 4}\end{array}$ & $\begin{array}{c}\text { Michigan state Natural gas rates } \\
\text { (\$/MMBTU) }\end{array}$ \\
\hline July & 14.00 \\
\hline August & 14.57 \\
\hline September & 12.48 \\
\hline October & 10.04 \\
\hline November & 8.85 \\
\hline December & 8.99 \\
\hline
\end{tabular}


Preprint: Aishwarya Mundada, Kunal Shah, Joshua M. Pearce. Levelized cost of electricity for solar photovoltaic, battery and cogen hybrid systems, Renewable and Sustainable Energy Reviews 57, (2016), 692-703.

Table 6: Capacity factor for PV and CHP module.

\section{Capacity factor PV module Capacity factor CHP module}

13\% (minimum of 3.3 sun hours for Houghton) $\quad 55 \%$

15.3\% (Houghton from simulation) $\quad 36 \%$

18\% (maximum 4.1-4.4 sun hours for Houghton) $\quad 14 \%$

\section{Figure Captions:}

Figure 1: Simplified

Block diagram of $\mathrm{PV}+\mathrm{CHP}+$ Battery hybrid system.

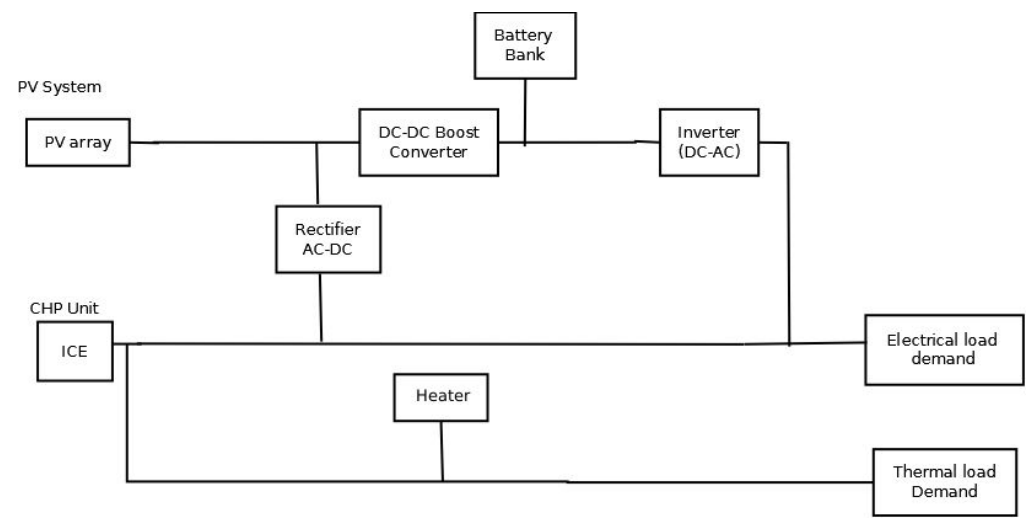

Figure 2: Region:

Michigan-Houghton. Average hourly energy produced per month by PV, CHP and battery units to meet the load demand.

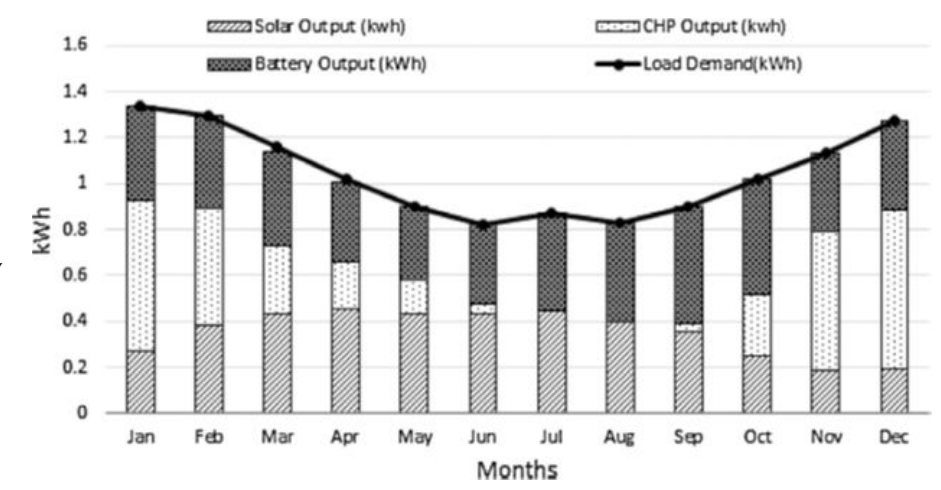


Preprint: Aishwarya Mundada, Kunal Shah, Joshua M. Pearce. Levelized cost of electricity for solar photovoltaic, battery and cogen hybrid systems, Renewable and Sustainable Energy Reviews 57, (2016), 692-703.

Figure 3: The levelized cost of electricity for central oas generation, which depends on the current electricity rates in the residential sector of Houghton, MI with varying escalation rates determined with NRELs LCOE calculator [93].
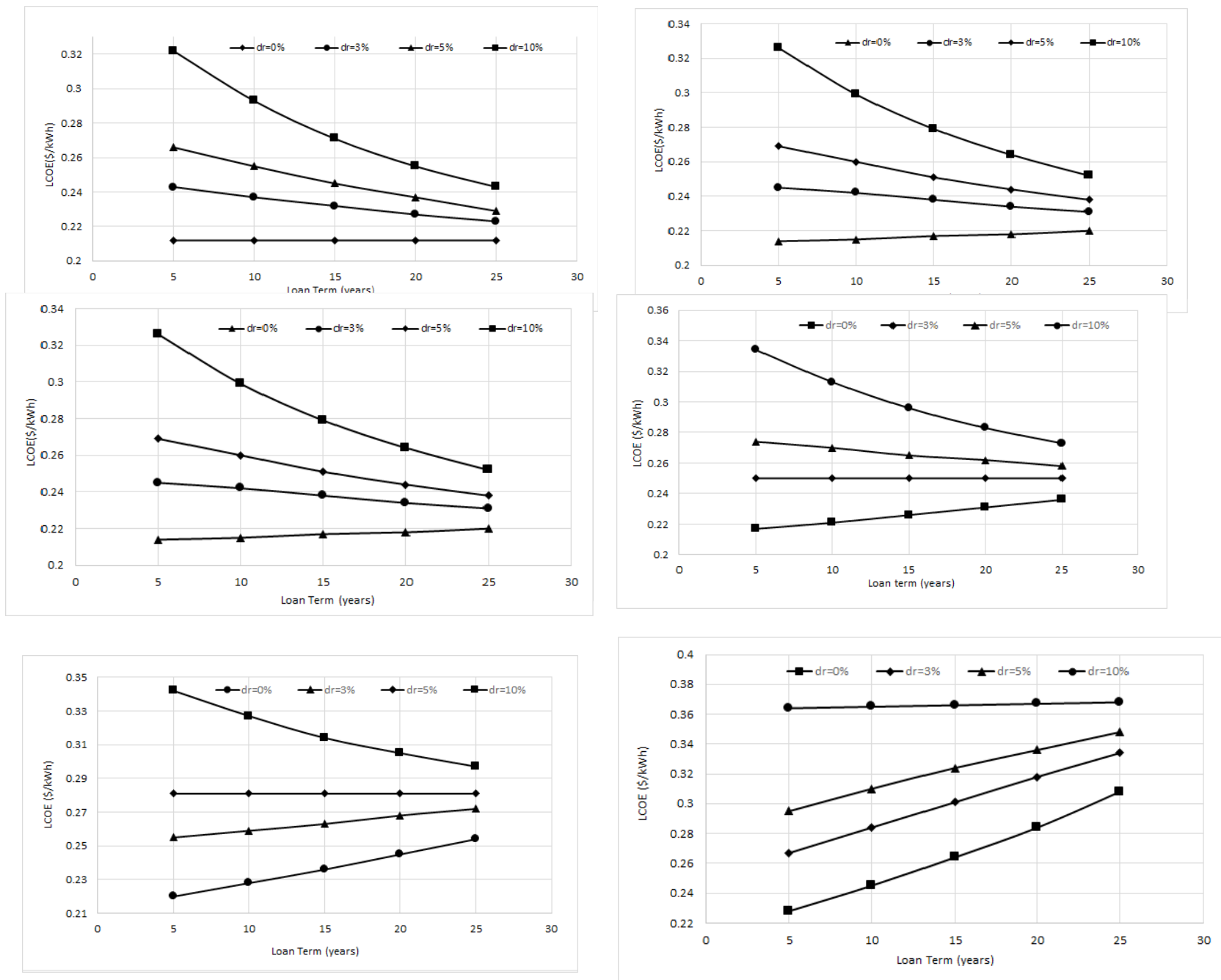

Figure 4: LCOE of the system for varying discount rate $(0 \%, 3 \%, 5 \%, 10 \%)$ and interest rates $(\mathrm{A}=0 \%, \mathrm{~B}=1 \%, \mathrm{C}=2 \%, \mathrm{D}=3 \%, \mathrm{E}=5 \%, \mathrm{~F}=10 \%)$.

Assumptions: Installation cost of $\mathrm{PV}=\$ 4 / \mathrm{W}$, $\mathrm{CHP}=\$ 1950 / \mathrm{kW}$ and battery $=\$ 2,000 / \mathrm{kWh}$, the total energy output $=14,000 \mathrm{kWh} /$ year, degradation rate $=0.5 \% / y e a r$ and loan term of 25 years. 
Preprint: Aishwarya Mundada, Kunal Shah, Joshua M. Pearce. Levelized cost of electricity for solar photovoltaic, battery and cogen hybrid systems, Renewable and Sustainable Energy Reviews 57, (2016), 692-703.
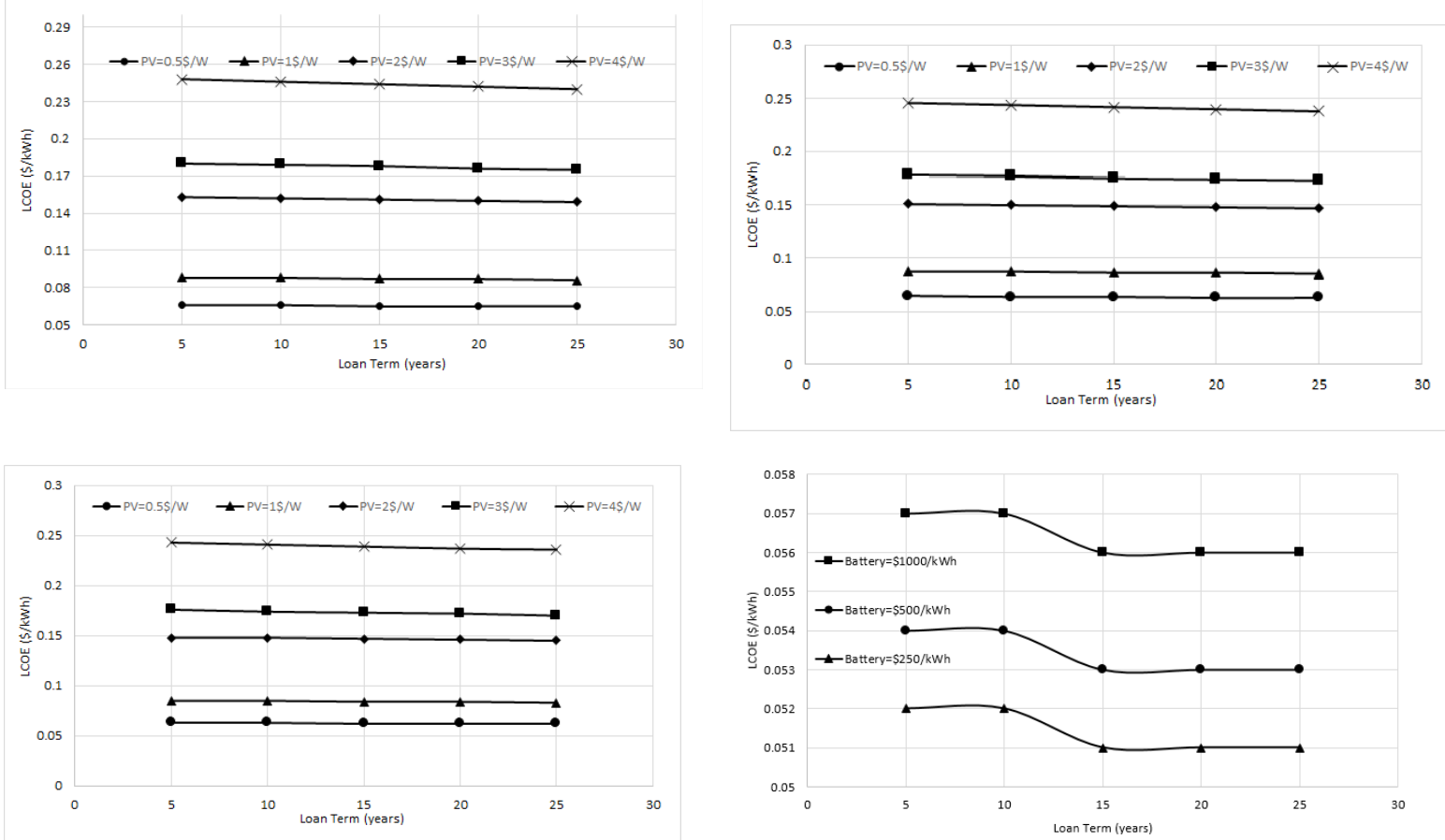

Figure 5: LCOE of the system for varying installation cost of PV $(0.5 \$ / \mathrm{W}, 1 \$ / \mathrm{W}, 2 \$ / \mathrm{W}, 3 \$ / \mathrm{W}, 4 \$ / \mathrm{W})$ and CHP capital cost $(\mathrm{A}=\$ 1400 / \mathrm{kW}, \mathrm{B}=\$ 1000 / \mathrm{kW}, \mathrm{C}=\$ 500 / \mathrm{kW})$. Assumptions included installation cost of battery of $\$ 2000 / \mathrm{kWh}$, loan term is 25 years, degradation rate $=0.5 \% / y e a r$, total energy output $=14,000 \mathrm{Wh} /$ year, discount rate $=3 \%$ and interest rate $=2 \%$. Figure $3(\mathrm{D}): \mathrm{LCOE}$ of the system for varying installation cost of battery $(\$ 1000 / \mathrm{kWh}, \$ 500 / \mathrm{kWh}, \$ 250 / \mathrm{kWh})$ with minimum installation cost of PV and capital cost of the CHP module for loan term of 25 years. Assumptions included, degradation rate $=0.5 \% / y e a r$, installation cost of $\mathrm{PV}=\$ 0.50 / \mathrm{W}$, capital cost of $\mathrm{CHP}=500 \$ / \mathrm{kW}$, total energy output $=14,000 \mathrm{Wh} / \mathrm{year}$, discount rate $=3 \%$ and interest rate $=2 \%$.

Figure 6: LCOE of the system for varying the capacity factor of PV module $(13 \%, 15.3 \%, 18 \%)$ and hence the capacity factor of the CHP module $(55 \%, 36 \%, 14 \%)$.

Assumptions included loan term is 25 years, degradation

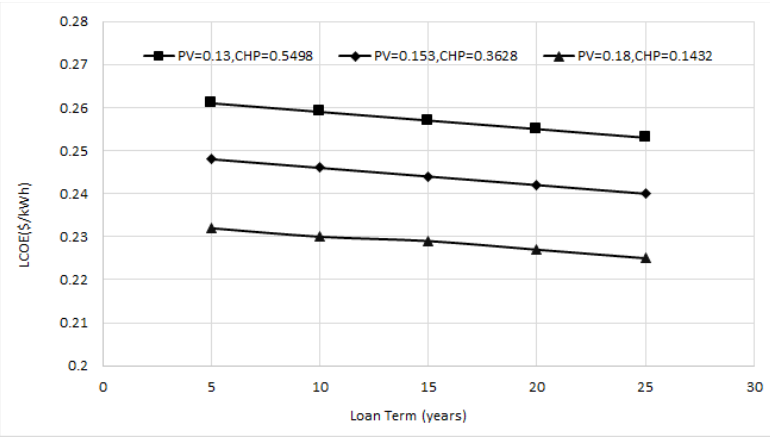
rate $=0.5 \% /$ year, installation cost of $\mathrm{PV}=\$ 4.00 / \mathrm{W}$, capital cost of $\mathrm{CHP}=\$ 1400 / \mathrm{kW}$, total energy output $=14,000 \mathrm{Wh} /$ year, discount rate $=3 \%$ and interest rate $=2 \%$. 
Preprint: Aishwarya Mundada, Kunal Shah, Joshua M. Pearce. Levelized cost of electricity for solar photovoltaic, battery and cogen hybrid systems, Renewable and Sustainable Energy Reviews 57, (2016), 692-703.

Figure 7: LCOE of the system for varying the efficiency of the CHP module $(85 \%$, $\quad 90 \%$, $95 \%, 98 \%$ ) for a loan term of 25 years. Assumptions included degradation rate of $0.5 \% / y e a r$ installation cost of $\mathrm{PV}$ is $\$ 4.00 / \mathrm{W}$,

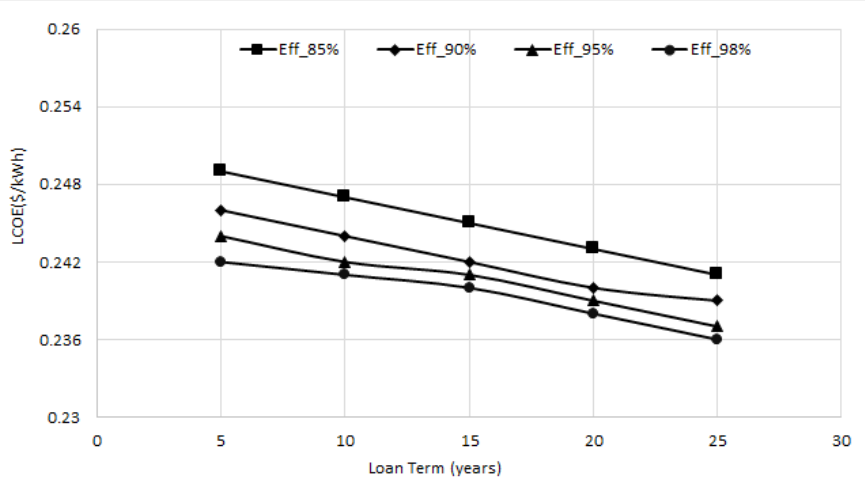
capital cost of CHP is $\$ 1400 / \mathrm{kW}$, total energy output is $14,000 \mathrm{Wh} /$ year, discount rate is $3 \%$ and interest rate of $2 \%$.

Figure 8: LCOE of the system for varying the rates of the natural gas (\$15, \$12, \$9, \$6 per MMBTU) used by CHP for a loan term of 25 years. Assumptions included degradation rate of $0.5 \% / y e a r$, installation cost of PV is $\$ 4.00 / \mathrm{W}$, capital cost of

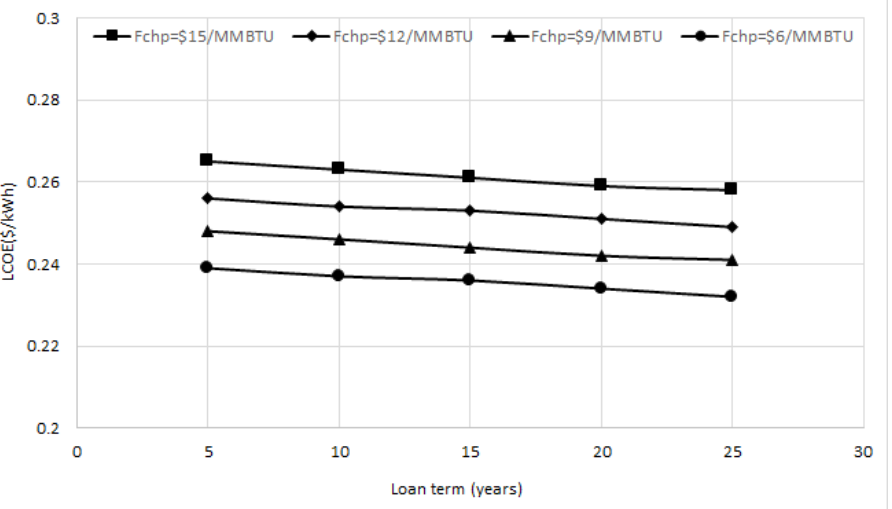
CHP is $\$ 1400 / \mathrm{kW}$, total energy output is $14,000 \mathrm{Wh} /$ year, discount rate is $3 \%$ and interest rate of $2 \%$. 